\title{
The Civil Society War: Fundraising Conflict Popularizes Financial Ratios and Uniform Accounting Standards through Public Policy
}

\author{
${ }^{1}$ Public and Nonprofit Administration, University of Wisconsin Milwaukee, Milwaukee, WI, USA, E-mail: willclev@uwm.edu
}

\begin{abstract}
:
The Civil Society War involved powerful interests clashing over fundraising policies for 25 years. The United Funds coerced leading health agencies to join their federated campaigns. These health agencies insisted on independent fundraising campaigns to maintain awareness of their causes, volunteers, and funds raised. Through the 1950s and 1960s, the United Funds expanded their focus from social services by entering the health field. An important tactic in this conflict was the development of fundraising permitting regulations across the country. These regulations often included fundraising efficiency ratios, limiting the percentage spent on fundraising divided by the donations received. These fundraising efficiency ratios, along with permitting regulations giving preferential treatment to United Funds resulted in numerous lawsuits. Ultimately, the fundraising regulations were declared unconstitutional by the U.S. Supreme Court based on freedom of speech under the First Amendment and equal representation under the Fourteenth Amendment. While the courts struck down the use of financial ratios, these metrics continue to be used in rating charities. One positive outcome of the conflict was the development of widely used uniform accounting standards. The health agencies drove development of these standards as a way to address a legitimate concern among a barrage of criticisms of their practices influenced by the conflict with the United Funds. The Civil Society War had lasting impacts on three main areas affecting nonprofit policy: fundraising regulation, use of financial ratios in charity evaluation, and uniform accounting standards.
\end{abstract}

Keywords: voluntary health agencies, United Way, nonprofit accounting standards, fundraising efficiency, fundraising regulation, financial ratios

DOI: $10.1515 /$ npf-2018-0024

\section{Introduction}

Internal policies of organizations can inspire changes in public policies, especially when powerful, competing interests are involved. Of interest here is the conflict between the United Funds, today known as the United Way, and seven leading health agencies. ${ }^{1}$ This conflict, starting in the late 1940s and lasting into the 1970s, occurred when the dominant American fundraiser, the United Funds, sought to expand funding from social services into health causes. This paper examines how competing policies about charitable fundraising led to a protracted conflict, creating consequential impacts in fundraising regulation, use of financial ratios, and uniform accounting standards for charities.

Conflicting policies may result in virtual warfare, reflected by the fundraising policies in this account of the Civil Society War. On one side, the United Funds advocated centralized coordination for both fundraising and allocation of donations within communities. In a single annual fundraising campaign, United Funds allocated donations to chosen social service charities and sought to extend this model to health charities. With an opposing policy, the largest voluntary health agencies (VHAs) insisted on independent fundraising campaigns conducted by individual organizations. These competitive campaigns educated the public about their causes, attracted volunteers, and generated donations.

Both sides in the Civil Society War referred to the conflict as a war. In 1947, the March of Dimes President Basil O'Connor warned that conflicting policies about fundraising would "break out an open warfare between the school of federated fundraising and the school of independent fundraising" (Financing Social Welfare address quoted in United Way of America 1977, 109). A decade later, advocating fundraising broadly inclusive of health causes, United Funds national President James Linen declared “This is war!" (United Way of America 1977, 140). 
The Civil Society War generated lasting impacts far beyond the organizations involved in the conflict. Both the United Funds and the group of VHAs meeting as the Seven Agencies Committee played instrumental roles influencing public policy and shaping public opinion about their causes. The United Funds was the only organization with the scope, influence, and interest to motivate the public policy changes creating municipal legislation across the country for fundraising permitting. United Funds action correlated with waves of municipal and state fundraising permit regulations that included fundraising efficiency ratios, a measure of the amount spent on fundraising divided by the amount raised. The reduced competition for donations through expanded federated fundraising sought by United Funds proved elusive, and independent fundraising drives have become the norm. Prevailing in the courtroom generated wins for the independent-minded VHAs through regulatory rollbacks. Ultimately, use of fundraising efficiency ratios in fundraising permitting was prohibited based on First Amendment grounds. However, the cultural influence persists in using financial ratios for evaluation of charities. A positive impact of the Civil Society War was the development of widely used uniform accounting standards. The Civil Society War was an important conflict shaping fundraising regulation, popularizing the use of financial ratios in the evaluation of charities, and developing uniform accounting standards for charities.

\section{Sources and Main Actors}

This paper draws on several sources, including numerous primary sources. Meeting minutes from the Seven Agencies Committee and other documents from the March of Dimes archives provide insight into actions during the Civil Society War. Legal cases and fundraising permitting regulations provide valuable information. Sources providing additional context include newspaper articles, magazine articles, newsletters, and other published materials from trade organizations, United Funds affiliates, and transcriptions of speeches made by various executives. Several histories about the health agencies and United Funds/United Way corroborate primary sources.

\subsection{Clash of Titans: United Funds on One Side}

The Civil Society War involved large organizations. The largest was the United Funds, which was comprised of local affiliates acting with a fair degree of autonomy but adopting the overall United Funds model. The fundamental value proposition of the United Funds was to conduct orderly and inexpensive fundraising with centralized decision making for fund allocations (Seeley et al. 1957). To many, a single fundraising appeal trumped the nuisance of multiple solicitations. Charities receiving United Funds allocations agreed to restrict their own fundraising. In the most extreme cases, charities receiving United Funds allocations agreed to conduct no independent fundraising (Rabinowitz, Simmeth, and Spero 1979). The United Funds model intended to limit competition for donations and perceived redundant expenditures for fundraising, while allocating funds where the United Funds deemed most beneficial to the community.

The United Funds had a preeminent position in American philanthropy. Summing donations received by all United Funds affiliates divided by total U.S. giving, United Funds received upwards of $7 \%$ of total U.S. giving between 1924 and 1948 (Jenkins 1950). ${ }^{2}$ Donations to United Funds were $4.5 \%$ of total U.S. giving by 1959 and, despite expanding into health causes, declined in percentage from that point, as shown in Figure $1 .{ }^{3}$ While United Funds giving increased above the rate of inflation, it lagged increases in both total US giving and giving to select national health agencies between 1964 and 1976 (Rabinowitz, Simmeth, and Spero 1979).

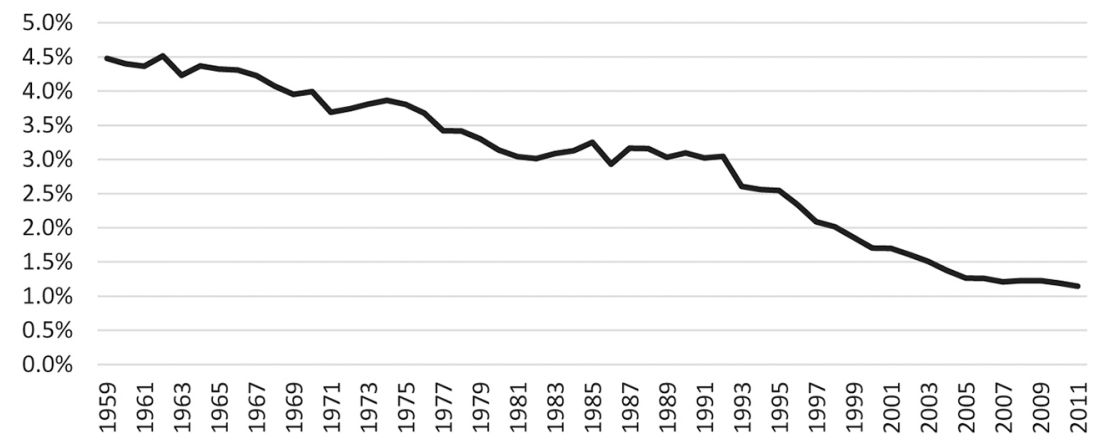

Figure 1: United Funds/Way giving as \% of total US Giving (Data from Hall and Burke (2006), United Way, \& Giving USA). 
United Funds increasingly dominated workplace fundraising campaigns, with payroll deduction streamlining the administrative process from pledge to donation (Barman 2006). The first United Funds drive in Detroit in 1949 reinforced unification of labor and management to support charities through a single workplace fundraising drive (Aft and Aft 2004; Brilliant 1990). Inspiring single workplace campaigns were findings that each fundraising drive cost an auto factory $\$ 40,000$ in lost productivity, and in-factory labor leaders wearied of coordinating multiple fund drives (Carter 1959). ${ }^{4}$ Solidifying their cooperation, labor insisted on participating in fund allocation decisions (Aft and Aft 2004; Brilliant 1990; United Way of America 1977). The United Funds' attempt to extend their domination of workplace giving for social services to include health-related fundraising generated stiff resistance by organizations targeted for inclusion in their federated campaigns.

\subsection{Seven Agencies Committee on the Other Side}

Seven leading VHAs resisted the United Funds' overtures to join federated campaigns. The Seven Agencies Committee included the largest American health advocacy charities, each focusing on a specific medical condition. Beyond public education, the health agencies' missions included supporting the development of treatments, cures, and preventatives for specific afflictions. Often this resulted in funding medical research, including funding development of laboratories or treatment facilities. These VHAs were not hospitals and, while many subsidized patient care, they generally did not directly provide patient care. The Seven Agencies Committee included the American Cancer Society, American Heart Association, Easter Seals (the major fundraiser for the National Society for Crippled Children and Adults), March of Dimes (the fundraising arm of the National Foundation for Infantile Paralysis), Muscular Dystrophy Association, National Multiple Sclerosis Society, and National Tuberculosis Association (now the American Lung Association). ${ }^{5}$

While other authors noted the Big Six agencies clashed with United Funds, this account details the cooperation of seven VHAs meeting as the ad hoc Seven Agencies Committee (Brilliant 1990; Seeley et al. 1957; United Way of America 1977). ${ }^{6}$ Executives from these VHAs met up to 10 times annually for some 25 years with the explicit purpose of staying out of United Funds federated campaigns. In this conflict, United Funds were not attempting to attract small health agencies to their campaigns. The largest of these VHAs were the National Tuberculosis Association and March of Dimes, which respectively received an estimated $0.60 \%$ and $0.30 \%$ of total US giving from 1924 to 1948, two of the largest charities at the time (Jenkins 1950). ${ }^{7}$ While these VHAs generated significant amounts of donations, the majority of these donations came in small amounts (Sills 1957). This conflict pitted formidable organizations against one another over fundraising policy: should fundraising be a federated and coordinated effort or should it be independent and competitive?

\section{Internal Policy Rationales}

Both sides in the Civil Society War articulated rationales for their fundraising policies. Zeal for unifying fundraising motivated United Funds operatives to federate fundraising beyond social services to include health causes. The fundamental reasons given for federation involved efficiency in fundraising and perceived fairness in allocation of donations among charities. Convinced of their rightness, United Funds operatives viewed federated campaigns in black-or-white terms, being with the United Funds or against them (Seeley et al. 1957). On the other hand, VHAs underlined the importance of individual fundraising campaigns to call attention to their causes and for attracting both donations and volunteers. Critical analysis found deficiencies in the rationales articulated by both sides (Seeley et al. 1957). Both sides talked past one another, and public tensions rose to the point of negotiating a truce to limit detrimental statements. However, attacks persisted, such that in 1956, Ray Eppert of the Detroit United Funds Advisory Committee noted that "... Cancer, Heart, and Polio are teaming up apparently in their attack in local communities, particularly in those places where a United Fund 'is imminent" (United Way of America 1977, 135). Countering this, the Seven Agencies Committee claimed the United Funds declined to sign a truce, and while half of the United Funds' national board of directors publicly favored a live and let live policy, several national United Funds executives insisted on an extermination policy for uncooperative VHAs (Crawford 1959d).

United Funds adopted a whole man theory of health, philosophically opposed to the existence of agencies associated with individual diseases. Research and treatment for the most pressing health needs was prioritized holistically, guided by experts (Carter 1959; United Way of America 1977). The strategic transformation from Community Chest to United Funds - including both social services and health charities - served the business purposes of boosting local United Fund affiliate success and increasing fundraising amounts, necessitating the United Funds co-opt the opposition (Brilliant 1990, Seeley et al. 1957). 
United Funds were not alone advocating for centralized coordination of health causes. The Rockefeller Foundation funded three studies of VHAs. The first was in 1924 at the urging of the Community Chests, the second in 1945 - the Gunn and Platt report - contributed to spurring the Civil Society War, and the third - the Hamlin report - reiterated the recommendation of centralized coordination of VHAs, along with advocating the standardization of financial accounting (Cutlip 1965; Gunn and Platt 1945; Hamlin 1961; Shryock 1957). Other advocates called for government coordination of education, health, and welfare (Meyer 1945). Beyond the nuisance of multiple solicitations, claims against VHAs included duplication of services, inadequate leadership, and ineffective provision for community health needs (Rogers 2014). VHAs opposed government or centralized control of health issues.

VHAs argued against the centralized coordination of health priorities to reinforce public awareness. Gunn and Platt (1945), while arguing for centralized coordination of health causes, noted popular support of VHAs and increased delivery of health services (Ducas 1946). Underlining the educational value of fundraising, a single fundraising appeal for all diseases was compared to the absurdity of advertising all refrigerators together (Ducas 1946). A 1953 survey of Hamilton County, Ohio residents found $84 \%$ of respondents could name no more than two agencies supported by United Funds (Glasser 1953). The need to share information among VHAs and coordinate messages advocating fundraising independence to counter opposition from United Funds inspired the formation of the Seven Agencies Committee (Ducas 1946). By 1948, members of the Seven Agencies Committee first drafted a guide instructing chapters to stay out of federated campaigns (Crabtree 1948; Preliminary Draft: Why we do not participate in joint fund-raising n.d.).

The Seven Agencies Committee members did not oppose the existence of the federated campaigns; these VHAs simply did not want to participate in them. Freedom of choice for both donors and charities constituted primary reasons for refusing federated campaigns. Contrary to the federated model, members of the Seven Agencies Committee advocated competitively building individual organizational brands through independent fundraising that incorporated public education about specific diseases.

Members of the Seven Agencies Committee had evolving policies for involvement with United Funds, with agencies progressively withdrawing from federated campaigns. Some affiliates of the Seven Agencies Committee members participated in United Funds campaigns. In the fall of 1952, at least 341 United Funds campaigns in the United States and Canada included one or more of the Big Six VHA national appeals (United Way of America 1977). In 1953, the American Cancer Society participated in 321 United Funds campaigns (United Way of America 1977). The March of Dimes created a policy against joining federated campaigns in 1944, although considered joining the first 1949 United Funds in Detroit, only to abstain after receiving confusing messages about designation of gifts on pledge cards (Data for State Representatives: Federated Fund-Raising 1951; Sills 1957). Participation in United Funds tied the hands of an organization like the March of Dimes in its fundraising, and allocations from the federated drives would not have met their financial needs. Basil O'Connor, the longtime leader of the March of Dimes, insisted polio has no budget, meaning that polio epidemics were unpredictable, creating the imperative to raise as much money as possible to subsidize patient care, promote basic research, and provide both professional and public education about polio (Policy statement of the National Foundation for Infantile Paralysis on federated fund-raising 1950). Organizations also needed to be able to take prudent risks with donors' funds to develop polio treatments and preventives, something unlikely with the constraints imposed by United Funds (O'Connor 1959).

VHAs withdrawing from federated campaigns cited lost awareness of their cause, receiving reduced donations, and attracting fewer volunteers in communities where they participated in federated campaigns. ${ }^{8}$ In the 1920s, the National Tuberculosis Association, citing detrimental effects on their Christmas Seals sales, instructed its chapters not to join federated drives and reiterated this in 1943, when pressure mounted to join the National War Fund Campaigns (Shryock 1957). Reinforcing this, an Alabama chapter of the National Tuberculosis Association participating in a federated campaign experienced reduced donations to $\$ 3,200$, only to rebound to $\$ 64,000$ after withdrawing and running an independent campaign (O'Connor 1947). Arguing against joining the federated campaigns, the March of Dimes estimated it earned 13.6\% more revenue remaining independent (Kingsbury 1952). By 1954, the American Cancer Society required affiliates to obtain approval from headquarters for continued participation with United Funds (United Way of America 1977). American Cancer Society President Eugene Pendergrass observed "the United Fund approach was 'slowing up the fight against cancer' [while] the identity of local units and their 'lifesaving message' was weakened by an all-purpose campaign," and his organization fully withdrew by 1960 (Fund Raising Muddle 1959). By the end of 1957, Easter Seals withdrew from United Funds (United Way of America 1977). The Muscular Dystrophy Association reported it lost money and identity in communities where it became involved with United Funds (Donahue 11/7/63). VHAs not meeting with the Seven Agencies Committee also reported exiting United Funds, such as the National Association for Mental Health and United Cerebral Palsy (Donahue 11/7/63; United Way of America 1977).

The VHAs took refraining from joining United Funds very seriously, refusing funds by returning checks and taking action against affiliates accepting federated funds. The March of Dimes refused funds in Buffalo 
and also refused funds raised for polio for two consecutive years in Matoon, Illinois (Data for State Representatives 1951; Crawford 1959c). The American Heart Association refused funds in Alabama and suggested the donations be returned to the public after repeatedly informing the United Funds before the campaign that any attempted donation would be refused (Donahue 1963a). The American Cancer Society announced a policy of refusing funds, with most local units complying (United Way of America 1977). The American Cancer Society disaffiliated 29 units for joining or remaining in United Funds, organized replacement units, and took the disaffiliated units to court in Indiana and Pennsylvania to recover funds (Crawford 1959b). Easter Seals amended its national bylaws in 1959 and again in 1962 to explicitly address disaffiliation for affiliates joining federated campaigns (Donahue 1963c, 1963d).

\section{Internal Policy Becomes Action}

The policy evolved for encouraging VHA involvement in United Funds campaigns. Hands-off guidance from United Funds headquarters stated "if the local board of any agency does not agree to cooperate with a United Funds effort, it is probably not wise arbitrarily to include that cause in the campaign" (Organizing a United Fund, CCC, March 1953, Bulletin 165, p.3 cited in United Way of America 1977). Some United Funds provided misleading information about the agencies included in their campaigns, exemplified by the Buffalo, New York case where the United Funds declared it "would raise funds for polio with or without the consent of the Buffalo and Erie County Chapter of the [March of Dimes] and offer the money to the chapter at the time of the drive" (Buffalo Evening News 3/7/51 article attached to Data for State Representatives 1951). The March of Dimes refused the $\$ 109,330$ check and declined to join the Federated Health Fund. This sort of funding refusal inspired evolution in policy toward VHA inclusion in United Funds drives. A decade later, the United Funds headquarters advised affiliates to "continue their efforts to solve the problem of multiple health appeals and health program inefficiency caused by national policies against participation in united fund raising" (United Community Funds and Councils of America 1962).

Polite invitations were issued to local VHA chapters to join local United Funds. Inclusion of VHAs created a precedent for other VHA chapters to join United Funds and allowed the United Funds to market their drives as raising funds for specific health concerns popular with donors. The national United Funds advised local affiliates in 1952 to "negotiate with local agency citizen representatives rather than the state or national headquarters" (United Way of America 1977, 122). However, when the invitations at the local level failed, the United Funds sometimes appealed to the VHAs' national headquarters. These appeals at the national level typically failed. For example, the Greater Anderson, South Carolina Associated Charities Review Board sent a letter to Basil O'Connor at the March of Dimes inviting the local chapter to join their united campaign. The request warned that the local media "will concentrate all of their advertisements for fund raising campaigns to this United Campaign" and local businesses agreed "to support only this Federated Drive" (Yarbrough 1951). Despite the warning, the March of Dimes did not join that campaign.

When these invitations failed, United Funds impeded independent fundraising campaigns. Since United Funds increasingly dominated workplace fundraising, shutting VHAs out of employers was a first step (Brilliant 1990). Volunteer leadership for fundraising campaigns often drew from recognized community leaders. A critical mass of volunteer leaders supporting the United Funds could exclude VHAs from fundraising in the main street business district (Yarbrough 1951). In Houston and Corpus Christi, Texas, United Funds supporters prohibited the Boys Scouts, a beneficiary of United Funds allocations, from helping with March of Dimes promotions, stopped the Retail Merchants Association from running March of Dimes promotions, prevented the Houston Independent School District from distributing March of Dimes coin cards, and stopped the local American Federation of Labor from endorsing VHAs (Barrows 1951). Despite the American Medical Association endorsing independent fundraising for VHAs and stating " $\mathrm{t}]$ he United Fund idea isn't shared by doctors" (Free 1959, 6), the March of Dimes chapter in Fayette County, Iowa became defunct, because all the doctors supported the county's United Funds (Clark 1961). In another tactic, United Funds supporters prevented VHAs from passing fundraising canisters in movie theaters (Brilliant 1990; United Way of America 1977).

Invitations sometimes escalated to threats. Starting by 1947, "united fund raising groups ... started including [VHAs] in their drives against [their] will, making public threats against [them] for not yielding to their wishes, and coercing [VHA] chapter members through economic boycott to throw over [national] fund raising policy and join their movement" (Voss \& Coss memo in Data for State Representatives 1951). The new United Funds of Portage County, Wisconsin "publicly stated its 'targets' are the American Cancer Society and the [March of Dimes], both of which conduct separate fund drives here through local county chapters" (Crawford 1959b). The public was directly urged not to support independent VHAs, exemplified by Detroit Torch Fund executive vice president Walter Laidlaw's statement "The giving public must stick together and decline to give to agencies 
outside United Funds auspices. It may seem hard, but it's the only way to resolve the problem" (Carter 1959, 145). Harold Prowell, president of the Pennsylvania United Funds noted in 1956 that we now "have the Salk vaccine. We have already licked polio. Now all that remains is to lick the [March of Dimes]" (Carter 1959, 152). National United Funds Vice President Ray Eppert underlined these threats in 1958, stating "it is up to the national health agencies to change their policies ... or suffer the consequences" (Carter 1959, 154).

Volunteering to lead a VHA fundraising campaign could prove hazardous. The March of Dimes created a clear policy allowing crossover volunteers between VHA and United Funds campaigns (Data for State Representatives: Federated Fund-Raising 1951; Sills 1957). Sometimes, volunteers agreeing to lead one of the health campaigns would be pressured by an employer to step down from leadership of that independent campaign. The March of Dimes Kansas City chapter chairman, Jay Wilson, was pressured to resign from his VHA position by his company's district manager along with Mrs Kip Robinson, who was pressured by numerous acquaintances to quit (Ducas 1952). Despite this intimidation, working around limitations resulted in a surprising $54 \%$ increase in donations to the March of Dimes in Kansas City from the previous year (Ducas 1952). In another example, "'My husband came home from the office one day and told me straight out that I had to quit,' says a young Southern mother who had resigned from her town's March of Dimes drive less than forty-eight hours after winning appointment to one of its key positions. 'He said that I was becoming too controversial and that his boss had complained about it'" (Carter 1961, 273). Resignations of 55 March of Dimes leaders resulted from United Funds pressure (Carter 1961).

The media provided some support for VHAs but generally supported United Funds, cooperating in press "blackouts" and limiting free publicity (Brilliant 1990). Newspaper editors repeatedly discussed appropriate levels of coverage charities should receive for fundraising campaigns (Friendly 1957; Hoyt 1954; Jones 1959; Leckrone 1959; Manning 1954; McCullough 1954; Owens 1959; Peters et al. 1952; Press: Are Editors Too Soft? 1959; Royster, Pope, and Wolff 1959; Wagnon 1957). Newspapers commonly published series of articles sympathetic with United Funds, such as the St Louis Globe-Democrat's inclusion of series in February, 1956 and late 1962 (Donahue 1962). In extreme cases, local media excluded VHAs from fundraising campaign publicity. The Kansas City Star eliminated coverage of March of Dimes fundraising campaigns in 1952 (Ducas 1952). In Spartanburg, South Carolina in 1966, the Chamber of Commerce objected to the national VHAs requiring abstention from United Funds and pledged to support local VHA leadership against their national organizations' policies. Encouraged by this pledge, the Spartanburg CBS affiliate aired a radio editorial against the VHAs and encouraged donors to only support United Funds as a message against the VHA national policies (Donahue 1966; Sanders 1966; WSPA 1966). CBS did not air March of Dimes spots nationally (Sherman 1966b). As early as 1954, the VHAs explored the possibility of coordinated public relations campaigns to counter the media support of federated fundraising (Barrows 1954). These discussions about coordinated public relations efforts continued into the 1960s (Crawford 1960; Sherman 1966b).

United Funds supported direct competitors of the seven VHAs, giving to alternative health groups (Brilliant 1990). The United Funds in Phoenix, Arizona threatened to end support of five health agencies if they did not combine with their drive, which the VHAs refused to do (Crawford 1960). When national VHAs did not join the federated campaigns, the United Funds would give to cooperative agencies addressing the same medical conditions (Brilliant 1990). For instance, United Funds affiliates allocated funds to the Michigan Cancer Foundation and the Sister Kenny Foundation that served polio patients, rather than the American Cancer Society and the March of Dimes (Brilliant 1990; United Way of America 1977).

Expansion into health causes led to separately coordinated united health campaigns (United Way of America 1977). United Funds launched separate federated health drives to concentrate fundraising for health concerns starting with the 1949 Detroit Torch Drive (Aft and Aft 2004; Brilliant 1990; United Way of America 1977). This initial separate health drive was followed by efforts in 1952 in Champaign-Urbana, Illinois; in 1955 in Durham, North Carolina; in 1956 in Lorain, Ohio; and in 1959 in Boston and Quincy, Massachusetts (Aft and Aft 2004; United Way of America 1977). By 1965, 110 communities in 33 states had United Health Foundations participating in health education and medical research (Donahue 1965). By 1967, around " 215 communities were members and program participants of United Health Foundations, Inc." (United Way of America 1977, 185).

\section{Influencing Public Policy and Publicity}

The conflict between the United Funds and Seven Agencies Committee members stepped into the public policy realm through fundraising regulation. By 1949, the United Funds national board advocated that local affiliates should ensure "that the community has a good local solicitation ordinance as protection against 'charity rackets' and that it is properly administered" (Community Chest and Councils of America Board of Directors 1949, 2). Municipal regulation of fundraising predated World War II, evidenced by the 1942 proposed model ordinance 
(Rhyne 1942). The National Health Council (NHC), the trade organization representing VHAs, articulated six criteria for equitable fundraising regulation: protect the public from dishonest opportunists; ensure generality of application; are not discriminatory, arbitrary, or capricious; avoid delegating legislative authority to the administering agency; uphold constitutional guarantees; and have practical and reasonable application (McMahon 1965, 1971). These six criteria were prefaced by discussion of regulations by the Seven Agencies Committee, several members of which circulated their own guides for appropriate legislation (Donahue 1963e). The United Funds appeared to desire to restrict fundraising outside their own campaigns starting no later than 1953. A history of the United Way stated that "[f]rom the [United Funds] point of view, local legal requirements would reduce fund-raising by agencies, particularly by those that were not affiliated with the federation" (Aft and Aft 2004, 127). Reflecting this, the March of Dimes management warned its chapters about rules "made to prevent them from holding a separate fund raising campaign through passage or the invoking of a city or county ordinance seeking to license all fund raising efforts and thus require a one-for-all campaign" (Ryan 1960). The Seven Agencies Committee anticipated increasing United Funds legislative lobbying in the spring of 1960 after the passage of home rule legislation in Indiana and Missouri enabling communities to pass local fundraising ordinances (Crawford 1959b).

Regulation was not always equitable, giving preferential treatment to United Funds. In a particularly egregious arrangement, the permitting regulations East Troy, Wisconsin specifically named the United Funds as the arbiter of appeals in the case of permit denial. Fundraising permit denials affected members of the Seven Agencies Committee. The National Tuberculosis Association was denied a permit two consecutive years in Ramsey County, Minnesota. Easter Seals faced permit denials throughout Minnesota after financial figures were unfavorably rearranged in applications submitted to the permitting agencies (Stickle 1967). Allen Grove, Wisconsin planned to withhold permits for all VHAs in 1965 (Boehm 1965). Hamblen, Tennessee denied all fundraising permits except for the United Funds (Brody 1968). Other permit denials will be discussed below in the context of the lawsuits they sparked.

Municipal rules for fundraising permits were eventually consolidated into state rules. Municipal rules tended to require submission of statistical information specific for that municipality. For larger charities, especially those operating nationally, these differences complicated accounting and increased reporting expenses. For instance, in Los Angeles County, each of the 30 separate municipalities had their own fundraising permitting process. To solicit in the entire county, charities compiled different financial reports to comply with the demands of each municipality, increasing costs by requiring allocation of expenses to different municipalities for campaigns including several cities. Consolidating these rules at the state level reduced the administrative burden on charities of complying with fundraising permits at the municipal level, while providing an equivalent regulatory oversight of fundraising (Barber 2012).

Permitting regulations included a weapon of choice, the fundraising efficiency ratio limit. This ratio divided the incurred fundraising expenses by the funds raised. United Funds, long interested in fundraising efficiency, raised concerns about fundraising expenses after calculating a $26 \%$ ratio for the National Tuberculosis Association's 1923 campaign (Shryock 1957). A fundraising efficiency ratio limit was often set at $25 \%$, meaning no more than one quarter of funds raised could be incurred as expenses. ${ }^{9}$ If the efficiency ratio of either a proposed fundraising campaign or the previous year's results exceeded the limit, a fundraising permit could be denied. As use of fundraising rules evolved, fundraising efficiency ratio limits effectively excluded some charities from competing for donations (Espinoza 1991).

Percentage-based fundraising efficiency ratios may not do more than protect charities from unscrupulous professional fundraisers (Steinberg and Morris 2010). A study of the Indianapolis United Funds noted that "such laws are difficult to enforce ... [and] that police control of solicitation does not provide, by itself, a sufficiently good method of controlling solicitations" (Seeley et al. 1957, 389). Indianapolis inconsistently enforced fundraising rules, reflected by a "number of appeals which have seemed to be in violation of the ordinance and yet have gone unpunished, it would appear that the ordinance is not very strictly enforced" (Seeley et al. 1957, 388). In 1968, the Savannah, Georgia Solicitations Review Board was reactivated, pressured by United Funds, and an ordinance passed to give 'teeth' to its determinations (Davis 1968; O'Connor 1968). Illinois and New York prosecuted organizations for fraud if fundraising and administrative expenses exceeded $50 \%$ (Metz and Rassin 1967). Regulation adding administrative burden and reporting increased costs, contrary to one aim of efficiency-based regulations. Further undermining fundraising regulation, one U.S. Supreme Court case struck down the use of fundraising efficiency permitting limits, partly because the court found the statute in question was not tailored narrowly enough to prevent fraud against the donating public (Riley vs. National Federation of Blind 1988).

United Funds touted their fundraising efficiency ratio, estimated between 4.1 to $12 \% .{ }^{10}$ However, while VHAs reported United Funds' average fundraising efficiency ratio at $8.9 \%$, they identified United Funds affiliates with ratios of $17.1 \%, 17.3 \%$, and $24.3 \%$ and some joint campaigns with ratios as high as $40-50 \%$ (Preliminary draft: Why we do not participate in joint fund-raising n.d.). Since their program was fundraising, 
United Funds eventually suggested their fundraising expenses should be accounted for as a program expense, reducing their fundraising efficiency ratio to $0 \%$ (Massey 1967; Sherman 1967b).

Fundraising efficiency ratios can be misleading for comparing charities due to differences in fundraising costs and reporting. Expense structures in charities are sufficiently different to defy easy comparison (EckhartQueenan, Etzel, and Prasad 2016). Fundraising costs differ between charities, such as higher costs for new charities compared to older and established charities. Unpopular causes typically require higher fundraising expenses. Charities may incur expenses and generate related revenue in different accounting periods, which creates a mismatch in comparative figures. Using a single benchmark to evaluate all charities is as misguided as making investment decisions using the same metric to evaluate both an emerging biotechnology company and a mature public utility, industries with fundamentally different financial characteristics.

Evaluating charities using financial ratios created a myth that charities spending very little on overhead are the most worthy of donors' contributions. This overhead myth may lead to a starvation cycle, where nonprofits deprive themselves of investments needed to develop adequate organizational infrastructure (Gregory and Howard 2009). The charity watchdog groups BBB Wise Giving Alliance, GuideStar, and Charity Navigator publicly urged donors to reduce reliance on financial ratios, noting the myth advocating low overhead costs actually hurts charities more than it improves performance (Taylor, Harold, and Berger 2013). To manage fundraising efficiency ratios, charity managers may manipulate accounting practices, especially when joint costs involve both fundraising and public education. Since public education about a charity's mission has positive value, some charities allocate a disproportionate share of joint costs to programs (Steinberg and Morris 2010). In the extreme, charities report zero dollars in fundraising expenses, with $37 \%$ of the charities generating at least $\$ 50,000$ in total revenue reporting no fundraising expenses on their Forms 990 (Hager, Pollak, and Rooney 2004).

Public education in the form of information services, such as the National Information Bureau, was characterized as an important force against fraud, poorly administered agencies, redundant agencies, and wasteful solicitation techniques (Seeley et al. 1957). United Funds national leadership instructed affiliates to "[o]perate an active public information service regarding the agencies seeking support" (Community Chests and Councils of America Board of Directors 1949, 2). The National Information Bureau (NIB) had numerous United Funds ties among its directors and executives along with disproportionate United Funds financial support (Kirby 1962; Sherman 1966a). The Seven Agencies Committee members claimed the NIB reports lacked objectivity and completeness (Davis and Brashier 1965). Reporting problems evolved to the point that the NIB reporting standards became inconsistently applied to evaluations and perceived as unreliable by the agencies (Sherman 1966a).

Unfortunately for VHAs, misleading NIB reports sometimes contributed to bad publicity for individual agencies (Donahue 1963d). NIB rearranged financial data supplied by the National Tuberculosis Association in Cleveland, Ohio to create the impression of high non-program expenses, resulting in unfavorable publicity and loss of support (Donahue 1963b). Soon after this, the NIB arbitrarily divided expenses into program and nonprogram categories and credited any subsequent errors to lack of standard accounting practices and insufficient NIB staff (Donahue 1963c). In their ratings, the NIB disapproved the American Heart Association and National Tuberculosis Association, while charging the American Heart Association and American Cancer Society with unethical promotion (Brashier 1966).

\section{Legal Challenges to Fundraising Permit Regulations}

Charities challenged the constitutionality of fundraising permitting regulations through lawsuits. ${ }^{11}$ One constitutional objection was the fundraising efficiency ratio violated First Amendment freedom of speech principles. A second constitutional objection was the exemption of United Funds from permitting requirements and naming United Funds as the arbiter of disputes involving the permitting rules, both violating Fourteenth Amendment equal protection principles.

The Seven Agencies Committee unanimously agreed no objective basis existed for fundraising efficiency ratio limits (Stickle 1967). Differences in fundraising costs occurred between organizations along with geographic area, campaign techniques, and when acts of God interfered with campaigns. More pointed objections to fundraising efficiency ratio limits were administratively increased costs, such as compliance with inconsistent regulatory requirements across jurisdictions and local pressures against independent fundraising by federated campaigns (O'Connor 1970).

The American Cancer Society challenged the City of Dayton's denial of their fundraising permit, because the agency refused to join the United Funds despite being issued fundraising permits in previous years. In the case decision, the Supreme Court of Ohio sided with the American Cancer Society, because "the only reasons given by the board for [the permit] denial were that the permit granted to the applicant the prior year was 
conditioned upon it becoming a member of the [United Funds], and that the [United Funds] had collected $\$ 25,000$ which was available for use against cancer" (American Cancer Society, Inc. et al. v. City of Dayton 1953, 226).

Applying First Amendment arguments, the March of Dimes lost its appeal against the City of Fort Worth for denying its 1966 fundraising permit. The permit application allegedly exceeded the allowable fundraising efficiency ratio of $20 \%$ (National Foundation v. Fort Worth 1969). The March of Dimes argued that any fundraising efficiency ratio limit violated First Amendment free speech protections. While not reported in the court decision, the March of Dimes internally discussed that their permit application figures were arbitrarily rearranged by the city to generate a $40 \%$ ratio, above the regulatory limit and producing adverse publicity (Donahue 1967; Russell and Voss 1970; Sherman 1967a; Stickle 1967). The March of Dimes appealed this case to the U.S. Supreme Court, which declined to hear the case.

Applying Fourteenth Amendment arguments, the Chicago affiliate of the American Heart Association sued after a fundraising permit denial in Park Ridge, Illinois (Davis 1962c). The Chicago Heart Association sued the City of Park Ridge to challenge the poorly defined permitting process that exempted the United Funds as a clear violation of the Fourteenth Amendment. In its 1961 decision, the Seventh Circuit of the U.S. Court of Appeals agreed that "it is obvious that the exemption of the [United Funds] by name constitutes a deprivation of the equal protection of the laws" (Adams v. City of Park Ridge 1961, 589-590).

It would be more than a decade after the March of Dimes lost its appeal in Ft Worth until the U.S. Supreme Court heard three cases that eliminated fundraising efficiency ratios as an element of fundraising permit issuance. These three cases, often referred to as the Riley trilogy, included Village of Schaumburg v. Citizens for a Better Environment (1980), Secretary of State v. Joseph H. Munson Co. (1984), and Riley v. National Federation of the Blind (1988). Permitting regulation based on fundraising efficiency ratios and providing preferential treatment to United Funds were found unconstitutional based on both the First Amendment principle of freedom of speech and the Fourteenth Amendment principle of equal protection. The willingness of the U.S. Supreme Court to hear these cases was likely influenced by the shift of regulating fundraising from the municipal level to the state level (Barber 2012).

\section{Uniform Accounting Standards a Beneficial Outcome}

A beneficial outcome of the Civil Society War was the development of widely used uniform accounting standards for charities. Lack of uniform accounting standards created confusion and lack of transparency in evaluating financial information for charities. The previously mentioned Hamlin Report funded by the Rockefeller Foundation called for national oversight of VHAs and development of uniform accounting standards (Hamlin 1961). Members of the Seven Agencies Committee unanimously rejected the call for national oversight of VHAs (Donahue 1962). However, VHAs supported the call for uniform accounting standards. United Funds had issued uniform accounting guidance in 1945 (Accounting in Community Chests: Principles and Methods 1945). However, the Hamlin report recommendations indicated that the United Funds accounting guidance was not used widely enough to produce uniform accounting among charities (Seville 1987).

The Seven Agencies Committee recognized that uniform accounting standards would create consistency among financial reports of charities and relieve pressure for centralized coordination of VHAs. Different allocation methods for program and non-program expenses among organizations created inconsistencies in the calculation of fundraising efficiency ratios on permit applications (Donahue 1963b). Shortly after the Hamlin Report's release, San Diego, New York State, and New York's Nassau County each independently drafted accounting regulations for charities, but each of these jurisdictions agreed to hold off implementation pending the development of the uniform accounting standards (Donahue 1962). The VHA's national trade group NHC worked with the National Social Welfare Assembly (NSWA) to develop the accounting standards (Standards of Accounting and Financial Reporting for Voluntary Health and Welfare Organizations 1964). The NHC had no funds budgeted for development of accounting standards (Davis 1962a). Financially backing the findings of the Hamlin report, the Rockefeller and Avalon foundations provided three years of funding for accounting standard development and requested participating VHAs also contribute (Donahue 1962).

Development of uniform accounting standards faced difficulties, particularly in expense allocation. Suggesting a fundraising efficiency ratio with a $15 \%$ maximum and new agencies allowed up to $25 \%$ in their first five years, divided the NHC and NSWA. The NHC argued including a maximum would result in misleading accounting (Donahue 1964a). Broadly accepted definitions for expense allocation could be elusive, such as the job descriptions and time records for employees, since these involved drawing the line between fundraising and program expenses (Donahue 1964c). Since agencies receiving United Funds allocations did not incur costs associated with the funding, significant discussion revolved around whether or not these agencies needed to allocate any costs to this funding (Donahue 1964b). United Funds attempted to supplement the uniform account- 
ing standards by providing its own accounting manual using functional classifications for expenses (Sherman 1967a).

The uniform accounting standards were developed and adopted relatively quickly. While the initial standards were published in 1964 (Standards of Accounting and Financial Reporting for Voluntary Health and Welfare Organizations 1964), Seven Agencies Committee members Multiple Sclerosis Society and National Tuberculosis Association planned to adopt the standards in 1963 (Davis 1962a, 1962b), with other Seven Agencies Committee members adopting them soon thereafter. To facilitate the adoption of the new accounting standards, the NHC held workshops in St Louis, Chicago, Oklahoma City, Los Angeles, and Fort Worth (Brody 1967; Davis 1966). These workshops were partially motivated by cities like St Louis prematurely requiring the standards as legally binding in 1966, leaving some agencies unprepared for compliance (Davis 1966). New York state required use of the new standards by 1968 (Brody 1967; Davis 1968; Weinberg 1966). Highlighting the motivation of VHAs to comply with the new accounting standards compared to social service agencies, all the NHC members were generally in compliance with the new accounting standards by the end of 1966, while only 18 of the 37 NSWA-member welfare agencies had adopted the new standards by then (Brody 1967; Stickle 1967). By 1968, nearly the entire health field conformed to the new accounting standards (Sherman 1967a).

\section{Conclusions}

The Civil Society War involved large organizations clashing over fundraising policies that created lasting impacts for the regulation of fundraising, donor evaluation of charities, and charity accounting standards. The core disagreement remained conflicting policies of federated versus independent fundraising. The United Funds persistently pursued actions to persuade members of the Seven Agencies Committee to join their federated campaigns, generating increasing resistance. These actions had lasting impacts far beyond the participants in the conflict. Any comprehensive study of the evolution of fundraising regulation, charity evaluation, or charity accounting standards needs to consider the Civil Society War.

Independent fundraising campaigns prevailed over federated giving advocated by the United Funds in the court of law and court of public opinion. Along with increasing their influence into the health field, primary motivations for the United Funds were centralizing fundraising to make solicitation more efficient and allocations more equitable from their perspective. While still substantial, the overall share of total U.S. giving received by the United Way, the successor to the United Funds, continues to decline. Each of the Seven Agencies Committee members remains significant, while numerous other disease-specific VHAs have also become substantial. While federated campaigns continue to play a role in fundraising, Americans have responded to independent campaigns, donating to a widening breadth of charitable causes rather than increasing giving to federated fundraising.

A critical weapon in the Civil Society War was permitting regulation incorporating fundraising efficiency ratios. The wide range of fundraising efficiency ratios included in regulations indicates no consensus on an appropriate percentage. While $25 \%$ was a common fundraising efficiency permit limit, the range of percentages used suggests that no objective study ever calculated an optimal percentage of fundraising expenses to generate donations. Ultimately, the United States Supreme Court decided financial efficiency ratios for fundraising permits violated First Amendment free speech rights.

A positive outcome of the Civil Society War was the development of uniform accounting standards by charities. Uniform accounting standards allow evaluation of relative performance. While only examining financial results does not provide an adequate assessment of charity performance, consistency allows figures to be compared within and between organizations.

The use of financial ratios persists in charity evaluation. Many donors reportedly evaluate charities by how much they spend on programs versus administrative expenses, which can starve charities of resources needed to build the administrative infrastructure to effectively pursue their mission. Unfortunately, efficiency in fundraising or managing other financial resources has little correlation to the effectiveness of the programs run by a charity. While an organization may efficiently manage its finances and convincingly market to donors, program implementation may not effectively further the charity's mission.

The Civil Society War left American charities with important legacies that need to be considered in the evolution of fundraising regulation, charity evaluation, and charity accounting standards. Independent fundraising has become an important function for many charities. While uniform accounting standards have become universal, these standards facilitate inappropriate focus on financial ratios for charity evaluation. Managing to specific ratios creates questions about the accuracy of charity expense reporting while simultaneously creating problems for some charities as they starve themselves of the administrative resources needed to effectively pur- 
sue their mission. While participants in the Civil Society War focused on influencing each other, their actions and ripple effects impacted future generations of charities far more broadly.

\section{Notes}

1 What is today the United Way evolved through a number of identities. Initially, the Community Chests, and then the Community Chests and Councils, raised and allocated funds locally. Starting in 1949, individual affiliates started adopting a United Funds model that allocated some funds to national organizations, locally using varied names including the words united, fund, community, chest, council, etc. In 1956, the organization at the national level became the United Community Funds and Councils of America. In 1972, the organization changed its identity nationally to the United Way (Aft and Aft 2004; Brilliant 1990; United Way of America 1977). In this paper, the term United Funds refers to the organization and its individual affiliates.

2 Omissions likely understate the denominator in Jenkins' work (1950), overstating this percentage.

3 The $4.5 \%$ figure was calculated by dividing the donations received by all United Funds affiliates and subsequently United Way by total giving reported by Giving USA. United Funds and United Way donations were reported by Hall and Burke (2006) and directly from the United Way. Unfortunately, only the financial figures for the March of Dimes were found going back into the study period. On an inflationadjusted basis, the March of Dimes had steady donations since 1965, meaning they have also declined in percentage of US donations received (author's analysis of March of Dimes annual reports).

4 The \$40,000 figure for 1949 would be worth over \$400,000 in 2018 using the BLS CPI Inflation Calculator at https://data.bls.gov/cgibin/cpicalc.pl.

5 Using the names Easter Seals and March of Dimes helps the reader recognize these organizations, both of which had several name changes. The Seven Agencies Committee initially had six members, with the Muscular Dystrophy Association added in 1959 (Crawford 1959a). The Committee denied the 1964 membership petition by the National Cystic Fibrosis Research Foundation (Stickle 1964).

6 The Big Six identified in Seeley et al. (1957) and United Way of America (1977), included the American Red Cross, American Cancer Society, American Heart Association, Easter Seals, March of Dimes, and National Tuberculosis Association. The Seven Agencies Committee excluded the American Red Cross and included the five other Big Six agencies plus the Muscular Dystrophy Association and National Multiple Sclerosis Society.

7 The March of Dimes, formed in 1938, existed less than half of Jenkins's study period. Again, per note 2, the understatement of the total US giving denominator likely inflates these percentages.

8 While the VHAs relied on anecdotal evidence for their decisions, a later study found individuals surveyed on average could not identify more than one of 34 charities funded by the United Way (Keating, Pitts, and Appel 1981). Long (1976) compared the fundraising results of four of the Seven Agencies Committee members and found personal forms of solicitation increased contributions relative to impersonal forms.

9 The $25 \%$ figure was cited in Seeley et al. $(1957,582)$, note 113 and in regulations cited by Rhyne (1942). However, many jurisdictions adopted limits other than $25 \%$.

10 In guidance on campaign organization, a total of " 10 to $12 \%$ of the total campaign goal is considered totally reasonable" for administrative and fundraising expenses (Organizing a Community Chest 1946,3). The 4.1\% figure is from Federation Facts Book, 1956 United Community Campaigns (New York: United CFCA, 1956) cited in Seeley et al. (1957). United Way of America (1977) notes an average fundraising efficiency ratio of $10.8 \%$ in 1954 . Only four years later in 1958, the estimated United Funds efficiency ratio dropped to $4.5 \%$, compared to a ratio of $12 \%$ for the March of Dimes (United Way of America 1977).

11 For more detail on the legal action involving fundraising regulation, see Copilevitz (1997); Fisch, Freed, and Roditti (1974); Harris, Holley, and McCaffrey (1990); Hough (1953); and Steinberg (1988).

\section{References}

Accounting in Community Chests: Principles and Methods. 1945. New York, NY: Community Chests and Councils of America

Adams, v. 1961. City of Park Ridge, § 293 F.2d 565.

Aft, R. N., and M. L. Aft. 2004. Grassroots Initiatives Shape an International Movement: United Ways since 1876. Cincinnati, OH: Philanthropic Leadership.

American Cancer Society v. City of Dayton. 1953. §114 NE 2d 219.

Barber, P. 2012. “Regulation of U.S. Charitable Solicitations since 1954." Voluntas: International Journal of Voluntary and Nonprofit Organizations $23(3): 737-62$.

Barman, E. 2006. Contesting Communities: The Transformation of Workplace Charity. Stanford, CA: Stanford University Press.

Barrows, R. H. 1951 July 16. Planning Committee for Federated Fund Raising Problems, memo. Medical Program Records, (Committees: Federated Fund Raising Committee: 1951-1958, Box 10 of 16). White Plains, NY: March of Dimes.

Barrows, R. H. 1954 April 29. Informal Meeting of Five of the Major Health Agencies, memo. Medical Program Records, (Committee VHA 43-54, Box 16 of 16). White Plains, NY: March of Dimes.

Boehm, D. E. 1965 November 5. Allen Grove, Walworth County, memo. Government Relations (State and Local) Records 1939-1976, (Wisconsin: Solicitation - Allen Grove, East Troy, 1959-1965, Box 4 of 4). White Plains, NY: March of Dimes.

Brashier, P. C. 1966 February 7. Seven Agencies Committee February 4, 1966 Minutes, Minutes. Medical Program Records, (Box 6 of 16). New York, NY: March of Dimes.

Brilliant, E. L. 1990. The United Way: Dilemmas of Organized Charity. New York, NY: Columbia University Press.

Brody, W. 1967 January 12. Seven Agencies Committee January 6, 1967 Minutes, Minutes. Medical Program Records, (Box 6 of 16). New York, NY: March of Dimes.

Brody, W. 1968 January 5. Seven Agencies Committee January 5, 1968 Minutes, Minutes. Medical Program Records, (Box 6 of 16). New York, NY: March of Dimes. 
Carter, R. 1959 November. “The Race for Your Charity Dollars: An Alarming Report that Reveals How a Bitter Struggle for Fund-Raising Control Threatens the Very Purposes for Which You Contribute Your Time and Money." Cood Housekeeping 149: 62-63.

Carter, R. 1961. The Gentle Legions. Garden City, NY: Doubleday.

Clark, W. S. 1961 October 28. Medical Relations of National Foundation Chapters: A Current Review; A Report to the Committee on the Relationships between Medicine and Allied Health Agencies (Shipman Committee of the American Medical Association), Report. Medical Program Records, (in file "Seven Agencies Committee: Medical Relations of National Foundation Chapters", Box 6 of 16). New York, NY: March of Dimes Archives.

Community Chests and Councils of America Board of Directors. 1949 April 20. Recommendation for Local and State Action to Bring about More Orderly Methods of Raising and Allocating Funds for Voluntary Health and Welfare Agencies, Corporate Coal Outline. Medical Program Records, (Poliomyelitis: VHAs 43-54, Box 16 of 16). White Plains, NY: March of Dimes.

Copilevitz, E. 1997. “The Historical Role of the First Amendment in Charitable Appeals." Stetson Law Review 27: 457-72.

Crabtree, C. H. 1948 September 14. Federated Fund Raising Manual, memo. Medical Program Records, (Manuals: Fund Raising Manuals, 19481972, Box 10 of 16). White Plains, NY: March of Dimes.

Crawford, W. 1959a April 24. MDA Acceptance to Six Agencies Committee 4/24/59, letters. Medical Program Records, (Poliomyelitis: Voluntary Health Agencies, 1955-1959, Box 16 of 16). White Plains, NY: March of Dimes.

Crawford, W. 1959b July 10. Seven Agencies Committee Meeting Minutes July \& September, 1959, minutes. Medical Program Records, (Poliomyelitis: Voluntary Health Agencies, 1955-1959, Box 16 of 16). White Plains, NY: March of Dimes.

Crawford, W. 1959c March 16. Six Agencies Committee March 16, 1959 \& April 13, 1959 Minutes, minutes. Medical Program Records, (Poliomyelitis: Voluntary Health Agencies, 1955-1959, Box 16 of 16). White Plains, NY: March of Dimes.

Crawford, W. 1959d January 12. Six Agencies Committee Minutes January, 1959, minutes. Medical Program Records, (Poliomyelitis: Voluntary Health Agencies, 1955-1959, Box 16 of 16). White Plains, NY: March of Dimes.

Crawford, W. 1960. Seven Agencies Committee July 8, 1960 Minutes, Minutes. Medical Program Records, (Box 6 of 16). New York, NY: March of Dimes Archive.

Cutlip, S. M. 1965. Fund Raising in the United States: Its Role in America's Philanthropy. New Brunswick, N]: Rutgers University Press.

Data for State Representatives: Federated Fund-Raising. 1951. "Manual. Medical Program Records, (Manuals: Fund Raising Manuals, 1948-1972, Box 10 of 16)."White Plains, NY: March of Dimes.

Davis, L. 1962a. Seven Agencies Committee January, 1962 Minutes, Minutes. Medical Program Records, (Box 6 of 16). New York, NY: March of Dimes Archive.

Davis, L. 1962b March 12. Seven Agencies Committee March 12, 1962 Minutes, Minutes. Medical Program Records, (Box 6 of 16). New York, NY: March of Dimes.

Davis, L. 1962c May 1. Seven Agencies Committee May1, 1962 Agenda, Agenda. Medical Program Records, (Box 6 of 16). New York, NY: March of Dimes.

Davis, L. 1966 September 22. Seven Agencies Committee September 9, 1966 Minutes, Minutes. Medical Program Records, (Box 6 of 16). New York, NY: March of Dimes.

Davis, L. 1968 June 19. Seven Agencies Committee June 14, 1968 Minutes, Minutes. Medical Program Records, (Box 6 of 16). New York, NY: March of Dimes.

Davis, L., and P. C. Brashier. 1965 December 14. Seven Agencies Committee November 5, 1965 Minutes, Minutes. Medical Program Records, (Box 6 of 16). New York, NY: March of Dimes.

Donahue, E. M. 1962 October 1. Seven Agencies Committee September 7, 1962 Minutes, Minutes. Medical Program Records, (Box 6 of 16). New York, NY: March of Dimes.

Donahue, E. M. 1963a February 15. Seven Agencies Committee February 5, 1963 Minutes, Minutes. Medical Program Records, (Box 6 of 16). New York, NY: March of Dimes.

Donahue, E. M. 1963b February 13. Seven Agencies Committee January 4, 1963 Minutes, Minutes. Medical Program Records, (Box 6 of 16). New York, NY: March of Dimes.

Donahue, E. M. 1963C April 1. Seven Agencies Committee March 1, 1963 Minutes, Minutes. Medical Program Records, (Box 6 of 16). New York, NY: March of Dimes.

Donahue, E. M. 1963d June 3. Seven Agencies Committee May3, 1963 Minutes, Minutes. Medical Program Records, (Box 6 of 16). New York, NY: March of Dimes.

Donahue, E. M. 1963e November 7. Seven Agencies Committee November 1, 1963 Minutes, Minutes. Medical Program Records, (Box 6 of 16). New York, NY: March of Dimes.

Donahue, E. M. 1964a February 25. Seven Agencies Committee January 8, 1964 Minutes, Minutes. Medical Program Records, (Box 6 of 16). New York, NY: March of Dimes.

Donahue, E. M. 1964b April 15. Seven Agencies Committee March 6, 1964 Minutes, Minutes. Medical Program Records, (Box 6 of 16). New York, NY: March of Dimes.

Donahue, E. M. 1964c May 29. Seven Agencies Committee May1, 1964 Minutes, Minutes. Medical Program Records, (Box 6 of 16). New York, NY: March of Dimes.

Donahue, E. M. 1965 April 27. Seven Agencies Committee March 5, 1965 Minutes, Minutes. Medical Program Records, (Box 6 of 16). New York, NY: March of Dimes.

Donahue, E. M. 1966 August 31. Seven Agencies Committee June 17, 1966 Minutes, Minutes. Medical Program Records, (Box 6 of 16). New York, NY: March of Dimes.

Donahue, E. M. 1967 June 16. Seven Agencies Committee June 16, 1967 Minutes, Minutes. Medical Program Records, (Box 6 of 16). New York, NY: March of Dimes.

Ducas, D. 1946 April 9. Unification of Private Health Agencies, memo. Medical Program Records, (Poliomyelitis: Voluntary Health Agencies, 1943-1954, Box 16 of 16). White Plains, NY: March of Dimes. 
Ducas, D. 1952 June 25. Kansas City, MO, Memo. Medical Program Records, (Committees, Federated Fund Raising Committee, 51-58, Box 5 of 16). White Plains, NY: March of Dimes.

Eckhart-Queenan, J., M. Etzel, and S. Prasad. 2016. “Pay What It Takes Philanthropy.” Stanford Social Innovation Review 14 (3): 36-41.

Espinoza, L. G. 1991. "Straining the Quality of Mercy." Abandoning the Quest for Informed Charitable Giving Southern California Law Review 64: 605-84.

Fisch, E. L., D. J. Freed, and E. C. Roditti. 1974. Charities and Charitable Foundations. Pomona, NY: Lond Publications.

Free, V. 1959. "Strong United Fund Helps." Bulletin of the American Society of Newspaper Editors 148: 6.

Friendly, A. 1957. "You, Too, Can Serve on Civic Committees: But Should You? NO." Bulletin of the American Society of Newspaper Editors 396: 1-2. The Fund-Raising Muddle. 1959, June 15. Newsweek, 53, 31-33.

Glasser, M. A. 1953 August 11. Survey of Public Attitudes toward Health \& Welfare Services in Hamilton, Ohio, Memo. Medical Program Records, (Box 16 of 16). White Plains, NY: March of Dimes.

Gregory, A. C., and D. Howard. 2009. “The Nonprofit Starvation Cycle.” Stanford Social Innovation Review 7 (4): 48-53.

Cunn, S. M., and P. S. Platt. 1945. Voluntary Health Agencies, an Interpretive Study. New York: The Ronald Press Company.

Hager, M. A., T. H. Pollak, and P. M. Rooney 2004. “What We Know about Overhead Costs in the Nonprofit Sector." Retrieved from Washington, DC: http://www.urban.org/UploadedPDF/310930_nonprofit_overhead1.pdf.

Hall, P. D., and C. B. Burke. 2006. "Nonprofit, Voluntary, and Religious Entities." In Historical Statistics of the United States: Earliest Times to the Present, vol. 2, edited by S. B. Carter, S. S. Gartner, M. R. Haines, A. L. Olmstead, R. Sutch, and C. Wright, 2-837-934. New York, NY: Cambridge University Press.

Hamlin, R. H. 1961. Voluntary Health and Welfare Agencies in the United States: An Exploratory Study, 1st ed. New York, NY: Schoolmasters' Press.

Harris, E., L. S. Holley, and C. J. McCaffrey. 1990. “Fundraising into the 1990s: State Regulation of Charitable Solicitation after Riley.” University of San Francisco Law Review 24 (Summer): 571-652.

Hough, R. L. 1953. “The Jehovah's Witnesses Cases in Retrospect.” The Western Political Quarterly 6 (1): 78-92.

Hoyt, E. C. 1954. "Some Midwest Ideas for Meeting the Problem." Bulletin of the American Society of Newspaper Editors 368: 9-10.

Jenkins, E. C. 1950. Philanthropy in America: An Introduction to the Practices and Prospects of Organizations Supported by Cifts and Endowments, 19241948. New York, NY: Association Press.

Jones, A. F. 1959. “We're Being Duped." Bulletin of the American Society of Newspaper Editors 148: 1-8.

Keating, B., R. Pitts, and D. Appel. 1981. “United Way Contributions: Coercion, Charity or Economic Self-Interest?” Southern Economic Journal 47 (3): 816-23. doi:10.2307/1057377.

Kingsbury, W. T. 1952 February 5. Committee on Federated Fund Raising: Non-Participation, Notes. Medical Program Records, (Committees, Federated Fund Raising Committee, 51-58, Box 5 of 16). White Plains, NY: March of Dimes.

Kirby, H. 1962 March 30. F. Strapp Request of March 14th, Memo. Medical Program Records, (Box 6 of 16). New York, NY: March of Dimes.

Leckrone, W. 1959. “This Year 1584 Children Were Clothed." Bulletin of the American Society of Newspaper Editors 417: 14-14.

Long, S. H. 1976. “Social Pressure and Contributions to Health Charities." Public Choice 28: 55-66.

Manning, J. 1954. “Detroit Likes Its Single, Inclusive Campaign." Bulletin of the American Society of Newspaper Editors 368: 9.

Massey, C. 1967 July 25. Standards of Accounting-UCFCA Exemption, Memo. Medical Program Records, (Box 6 of 16). New York, NY: March of Dimes.

McCullough, E. R. 1954. “What for Charity Besides Space?” Bulletin of the American Society of Newspaper Editors 368: 9.

McMahon, M. E. 1965. Viewpoints on State and Local Legislation Regulating Solicitation of Funds from the Public. New York, NY: National Health Council.

McMahon, M. E. 1971. Viewpoints on State and Local Legislation Regulating Solicitation of Funds from the Public, 2nd ed. New York, NY: National Health Council.

Metz, L., and R. Rassin. 1967. “Charitable Solicitation Acts - an Attempt to Curb Charity Cheats.” DePaul Law Review 16 (2): $472-77$.

Meyer, E. 1945. "Judgment Day for the Private Welfare Agency." The Public Opinion Quarterly 9 (3): 338-45.

The National Foundation v. City of Fort Worth. 1969. § 415 F.2d 41.

O'Connor, B. 1947 October 16. Do We Want a Health Trust?, Speech. Medical Program Records, (Poliomyelitis: VHAs 43-54, Box 16 of 16). White Plains, NY: March of Dimes.

O'Connor, B. 1959. The Place of the National Voluntary Health Organization in American Life: Address to the Midwest Conference of United Community Funds and Councils of America. Chicago, IL: National Foundation.

O'Connor, J. J. 1968 September 12. Seven Agencies Committee Memo for September 13, 1962 Meeting, Memo. Medical Program Records, (Administration: License to Solicit 1948-1970, Box 6 of 16). White Plains, NY: March of Dimes.

O'Connor, J. J. 1970 August 11. The Inclusion of a Fixed Percentage of Fund-Raising Costs in Legislation Regulating Solicitation of Funds from the Public by Charitable Organizations, Joint Statement. Medical Program Records, (Box 6 of 16). White Plains, NY: March of Dimes.

Organizing a Community Chest. 1946. New York, NY: Community Chests and Councils, Inc.

Owens, H. 1959. "It All Started in Baltimore." Bulletin of the American Society of Newspaper Editors 417: 25.

Peters, R. D., J. A. Meckstroth, J. G. Champaigne, and A. T. Burch. 1952. “Independent Welfare Drives or United Appeal?” Bulletin of the American Society of Newspaper Editors 348: 9.

Policy statement of the National Foundation for Infantile Paralysis on Federated Fund-Raising. 1950, June. “Policy Statement. Medical Program Records, (Manuals: Manual for Chapters, 1950-1960, Box 10 of 16)." White Plains, NY: March of Dimes.

Preliminary Draft: Why We Do Not Participate in Joint Fund-Raising. n.d. "Manual. Medical Program Records, (Poliomyelitis: Voluntary Health Agencies, 1943-1954, Box 16 of 16)." White Plains, NY: March of Dimes.

Press: Are Editors Too Soft? 1959, March 16. Newsweek, 53, 60.

Rabinowitz, H. S., B. R. Simmeth, and ]. R. Spero. 1979. “The Future of United Way.” Social Service Review 53 (2): $275-84$.

Rhyne, C. S. 1942. Charitable, Religious, Patriotic and Philanthropic Solicitations-City Ordinances and Court Decisions-Models Ordinance Annotated, Washington, DC: National Institute of Municipal Law Officers.

Riley, v. 1988. "National Federation of the Blind of North Carolina, Inc." § 108 S Ct 2667. 
Rogers, N. 2014. Polio Wars: Sister Elizabeth Kenny and the Colden Age of American Medicine. New York, NY: Oxford University Press. Royster, V., J. Pope, and M. H. Wolff. 1959. “How about Christmas Funds?” Bulletin of the American Society of Newspaper Editors 416: 1-2. Russell, W. R., and G. P. Voss. 1970 March 6. The National Foundation V. City of Fort Worth, Memo. Medical Program Records, (Administration: License to Solicit 1948-1970, Box 6 of 16). White Plains, NY: March of Dimes.

Ryan, S. V. 1960 September 29. School Solicitation, memos \& court decrees. Medical Program Records, (Administrative License to Solicit 48-70, Box 2 of 16). White Plains, NY: March of Dimes.

Sanders, C. R. 1966 May 25. Letter to National TB Association Inviting Rebuttal to Editorial, Letter. Medical Program Records, (in file "Seven Agencies Committee 1966-1967", Box 6 of 16). New York, NY: March of Dimes Archives.

Secretary of State of Maryland v. Joseph H. Munson Co, Inc. 1984. §104 S Ct 2839.

Seeley, J. R., B. H. Junker, R. W. Jones, Jr., N C. Jenkins, M. T. Haugh, and I. Miller. 1957. Community Chest: A Case Study in Philanthropy. Toronto, ON: University of Toronto Press.

Seville, M. A. 1987. “The Evolution of Voluntary Health and Welfare Organization Accounting: 1910-1985." The Accounting Historians Journal 14 (1): $57-82$.

Sherman, I. 1966a February. Seven Agencies Committee February 4, 1966 Minutes, Minutes. Medical Program Records, (Box 6 of 16). New York, NY: March of Dimes.

Sherman, I. 1966b December 5. Seven Agencies Committee November 4, 1966 Minutes, Minutes. Medical Program Records, (Box 6 of 16). New York, NY: March of Dimes.

Sherman, I. 1967a November. Seven Agencies Committee September 18, 1967 Minutes, Minutes. Medical Program Records, (Box 6 of 16). New York, NY: March of Dimes.

Sherman, I. 1967b November 7. Seven Agencies Committee September 18, 1967 Minutes Correction, Memo. Medical Program Records, (Box 6 of 16). New York, NY: March of Dimes.

Shryock, R. H. 1957. National Tuberculosis Association, 1904-1954: A Study of the Voluntary Health Movement in the United States. New York, NY: National Tuberculosis Association.

Sills, D. L. 1957. The Volunteers: Means and Ends in a National Organization. Glencoe, IL: Free Press.

Standards of Accounting and Financial Reporting for Voluntary Health and Welfare Organizations. 1964. New York, NY: National Health Council and National Social Welfare Assembly.

Steinberg, R. 1988. “Economic Perspectives on Regulation of Charitable Solicitation.” Case Western Reserve Law Review 39 (3): $775-98$.

Steinberg, R., and D. Morris. 2010. "Ratio Discrimination in Charity Fundraising: The Inappropriate Use of Cost Ratios Has Harmful SideEffects." Voluntary Sector Review 1 (1): 77-95. doi:10.1332/204080510x497028.

Stickle, G. 1964 September 29. Seven Agencies Committee September 11, 1964 Minutes, Minutes. Medical Program Records, (Box 6 of 16). New York, NY: March of Dimes.

Stickle, G. 1967 March 7. Seven Agencies Committee March 3, 1967 Minutes, Minutes. Medical Program Records, (Box 6 of 16). New York, NY: March of Dimes.

Taylor, A., J. Harold, and K. Berger. 2013. “The Overhead Myth.” Retrieved from http://overheadmyth.com/.

United Community Funds and Councils of America. 1962 November. Policy and Program Re National Voluntary Health Agency Situation, Policy Statement. Medical Program Records, (Box 6 of 16). New York, NY: March of Dimes.

United Way of America. 1977. People \& Events: A History of the United Way. Alexandria, VA: United Way of America.

Village of Schaumburg v. Citizens for a Better Environment. 1980. §444 S Ct 620.

Wagnon, H. 1957. "You, Too, Can Serve on Civic Committees: But Should You? YES." Bulletin of the American Society of Newspaper Editors 396 $1-2$.

Weinberg, G. C. 1966 May. Seven Agencies Committee May 6, 1966 Minutes, Minutes. Medical Program Records, (Box 6 of 16). New York, NY: March of Dimes.

WSPA Radio. 1966. Editorial Supporting Spartanburg Chamber of Commerce [Editorial]. Spartanburg, SC: WSPA Radio (CBS Affiliate).

Yarbrough, J. C. 1951 July 10. Letter of Invitation to Join Anderson, SC Federated Campaign, Letter. Government Relations, State \& Local, (South Carolina: Solicitation Anderson, 1951, Box 4 of 4). White Plains, NY: March of Dimes. 